\title{
Influence of salt stress on growth and frost resistance of three winter cereals
}

\author{
Renata Matuszak-Slamani* and Aleksander Brzóstowicz \\ Chair of Physics and Agrophysics, West Pomeranian University of Technology, \\ Papieża Pawła VI nr 3, 71-459 Szczecin, Poland \\ Received February 22, 2014; accepted November 4, 2014
}

\begin{abstract}
A b s t r a c t. This paper presents results of a study on the in-

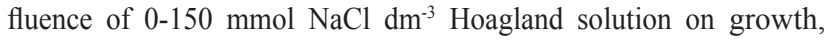
chlorophyll content, photosynthesis and frost resistance of seedlings of three winter cereals: wheat $-c v$. Almari, rye $-c v$. Amilo, and triticale $-c v$. Tornado. Sodium chloride at $25 \mathrm{mmol} \mathrm{dm}^{-3}$ caused better growth of wheat shoots and roots, both of fresh and dry matter. Higher concentrations of $\mathrm{NaCl}$ in the medium decreased the biomass of the tested seedlings. The influence of $\mathrm{NaCl}$ on the chlorophyll content in the seedlings varied. The conductometry method showed that the resistance of the cell walls of wheat and rye to low temperature decreased in the presence of $\mathrm{NaCl}$ in the growth medium. Luminescence has shown that seedlings that grew in $\mathrm{NaCl}$-containing medium indicated an impediment of electron flow at a lower temperature than the control plants.

$\mathrm{K}$ e y w or d s: $\mathrm{NaCl}$, frost resistance, growth, winter cereals
\end{abstract}

\section{INTRODUCTION}

Plants that grow in the natural environment are exposed to various unfavourable factors, which modify the intensity or disturb their growth, thereby causing temporary or irreversible destabilization of the organism.

The reaction of plants to a single stress factor, such as low temperature (Beck et al., 2007; Mahajan and Tuteja, 2005) or salinity (Chinnusamy et al., 2005; Flowers, 2004; Mohammadi et al., 2012; Munns, 2002), is fairly well recognized. The response of cultivated plants to stress caused by a number of stress factors factors is a more complex issue, as in natural conditions, plants are usually exposed to multistress. Since the area of saline soils increases in the world (Arzani, 2008; Munns, 2002) and plants, for example

*Corresponding author e-mail: Renata.Matuszak@zut.edu.pl winter rye, are exposed to both salt and low temperature, studies on the effect of combined stress factors seem to be of great importance.

As far as winter plants are concerned, their yield depends to a great extent on winter hardiness and frost resistance, which are conditioned by both genetic factors and the environment (Pocock et al., 2001; Starck et al., 1995, Veisz et al., 2001).

Climatic and soil conditions can modify plant frost resistance by modifying their frost hardening. Thus, it can be assumed that salinity of the growth medium, which is one of the important factors limiting plant cultivation, may affect plant frost resistance, providing the intensity of salt stress would not be overly intense and the plants would not perish.

Knowledge of plant response to various stresses, particularly to multistresses, is of great scientific and practical value. Selection of species and cultivars that show resistance to stress factors can lead to an increase in areas suitable for plant cultivation. Moreover, it can promote cultivation of plant forms that will possess mechanisms increasing their stress resistance.

The aim of this study was to assess the influence of growth medium salinity $(\mathrm{NaCl})$ on growth and frost resistance of some winter cereal cultivars. The study also aimed at an analysis of these effects, assuming that moderate salt stress might promote winter hardiness.

\section{MATERIAL AND METHODS}

The experiments were conducted in controlled conditions, using the Hoagland solution as a growth medium for winter cereals: wheat (Triticum asetivum L.) $c v$. Almari, rye 
(Secale cereale L.) $c v$. Amilo, and triticale (Triticosecale Wittm.) $c v$. Tornado. Sodium chloride solutions were mixed with the Hoagland solution 1:1 to obtain $\mathrm{NaCl}$ concentrations of $25,50,75,100$, and $150 \mathrm{mmol} \mathrm{dm}^{-3}$. Hoagland solution diluted with distilled water 1: 1 served as a control medium.

Kernels of the tested cereals were placed in the 'Szmal' germination apparatus (Kospin, Poddębice, Poland), 100 kernels per one, and then transferred into containers with Hoagland solution with various $\mathrm{NaCl}$ concentrations. The samples were kept in a microphytotron at $20^{\circ} \mathrm{C}$, photosynthetic photon flux density (PPFD) $200 \mu \mathrm{mol} \mathrm{m}^{-2} \mathrm{~s}^{-1}$, day/ night $12 \mathrm{~h} / 12 \mathrm{~h}$. Beginning with the third day, the temperature was decreased by $2^{\circ} \mathrm{C}$ per day to $10^{\circ} \mathrm{C}$. The plants were kept in these conditions for 28 days.

The cereal kernels were placed in distilled water in Petri dishes for one day. The next day, 20 kernels were transferred onto wet filter paper $(5 \times 22.5 \mathrm{~cm}), 1 \mathrm{~cm}$ off the upper edge, covered with a strip of wet filter paper, and rolled into tubes. These tubes were then put upright in glass dishes (three in one dish) containing a 1-cm layer of distilled water. $24 \mathrm{~h}$ later, the water was replaced by $\mathrm{NaCl}$ solutions, and the samples were placed in a miniphytotron $\left(20^{\circ} \mathrm{C}\right.$, PPFD $200 \mu \mathrm{mol} \mathrm{m}^{-2} \mathrm{~s}^{-1}$, day/night $12 \mathrm{~h} / 12 \mathrm{~h}$ ). The temperature was lowered by $3^{\circ} \mathrm{C}$ per day to achieve $10^{\circ} \mathrm{C}$ and 14 days later the process of hardening began. The PPFD was decreased to $60 \mu \mathrm{mol} \mathrm{m} \mathrm{m}^{-2} \mathrm{~s}^{-1}$, and the day/night period to $8 \mathrm{~h} / 16 \mathrm{~h}$. Simultaneously, the temperature was successively lowered with the rate $2^{\circ} \mathrm{C} / 24 \mathrm{~h}$ to $2^{\circ} \mathrm{C}$. After 14 days, the solutions were removed from the dishes, and the plants remaining in the filter-paper tubes were moistened every day with the proper $\mathrm{NaCl}$ - Hoaglands solutions, which lasted for 14 days.

The fresh and dry matter of the seedlings were analyzed by weight, with an accuracy of $0.0001 \mathrm{~g}$. The plants were dried for $12 \mathrm{~h}$ at $105^{\circ} \mathrm{C}$. An average weight of 1 seedling was calculated.

The portable photosynthesis meter (LCA-4 (ADC Bioscientific Ltd. Great Britain)) was used to measure the intensity of photosynthesis.

The optical density of leaf mesophyll was measured by SPAD-502 (Minolta Co. Ltd, Japan).

The result of these measurements was displayed digitally as the so-called SPAD units. Its value is proportional to the content of chlorophyll in the analyzed leaf surface $\left(6 \mathrm{~mm}^{2}\right)$ (Monje and Bugbee, 1992).

To assess the cell wall resistance to low temperature, a modified conductometric method was applied (Brzóstowicz and Prokowski, 2003). Shoots of each seedling were cut off at the seed, rinsed twice with distilled water, and placed in moist test tubes covered with cotton balls. These tubes (10 in each treatment) were placed in test tube holders; 5 such batches were transferred into 5 freezers. The control batch was kept for $24 \mathrm{~h}$ at $5 \pm 1{ }^{\circ} \mathrm{C}$. The remaining 4 batches were kept in the same conditions for only $15 \mathrm{~min}$ and next the temperature was lowered by $1^{\circ} \mathrm{C}$ per $5 \mathrm{~min}$ to achieve the desired temperature $\left(-14,-16,-18\right.$, and $\left.-20^{\circ} \mathrm{C}\right)$. The temperature was different for the various plant species in order to produce damage below or above $50 \%$. After $2 \mathrm{~h}$ of freezing the seedlings, the temperature was increased by $1^{\circ} \mathrm{C}$ per $5 \mathrm{~min}$ to reach $+5^{\circ} \mathrm{C} .12 \mathrm{~h}$ later, $7 \mathrm{ml}$ distilled water with a temperature of $5{ }^{\circ} \mathrm{C}$ was added to each test tube. After $4 \mathrm{~h}$ (including 30-min shaking), the conductivity of the consecutive solutions was measured using the CPC-551 conductometer (Elmetron, Poland). The solution was placed back into the test tube with the seedlings. The tested plants were then kept for $16 \mathrm{~h}$ in a freezer at $-30^{\circ} \mathrm{C}$ to achieve total frost kill. After quick thawing and warming to room temperature, $4 \mathrm{~h}$ after removal (including $30 \mathrm{~min}$ shaking), electrical conductance was measured again (maximum leakage of the electrolyte). The damage index 'ID' (Flint et al., 1967) for the given temperature of chilling was then calculated. This index expresses the percentage of damage of the tested object in relation to maximal damage that can occur after total destruction by low temperature. The frost resistance index in this method is the temperature $t_{50}$ which is read from the diagram of the dependence of the damage index on the freezing temperature. The lower the $t_{50}$ the greater is the frost resistance of the cell walls. The diagram facilitated the assessment of the precision of the $t_{50}$ assay after the absolute error calculation of the damage index had been done with the total differential method.

The conductometric method of the assessment of frost resistance was applied to hardened plants subjected to various salinity of the growth medium. Each experiment was repeated 10 times.

Parts of the first leaf ( $2 \mathrm{~cm}$ long) were taken at a distance $2 \mathrm{~cm}$ from the tip. The leaves were placed on strips of moist filter paper and kept in Petri dishes in a freezer at $5^{\circ} \mathrm{C}$, PPFD $200 \mu \mathrm{mol} \mathrm{m}{ }^{-2} \mathrm{~s}^{-1}$. Delayed luminescence (IDL) of chlorophyll was measured during the period of temperature dropping with a speed of $1^{\circ} \mathrm{C}$ per $1 \mathrm{~min}$, from 0 to $-20^{\circ} \mathrm{C}$, using a test stand developed by Brzóstowicz (1993), and modified by Brzóstowicz (2003) at the Department of Physics, Agricultural University in Szczecin. Previous studies (Brzóstowicz, 1990) had shown that $\mathrm{t}_{\mathrm{m}}$ (the temperature at which delayed luminescence was at its maximum), was well suited for the assessment of the sensitivity of the photosynthetic apparatus of plants to low temperature. The $t_{m}$ index informs about the temperature at which the electron transport between $Q_{A}$ and $Q_{B}$ was blocked at the acceptor site of photosystem II. A lower value of $\mathrm{t}_{\mathrm{m}}$ at constant measurement conditions indicates higher resistance of initial reactions within photosystem II to low temperature, hence higher potential of frost resistance.

These assays were conducted with hardened plants growing in a medium with a varied $\mathrm{NaCl}$ content, with 5 replicates for each object.

The statistical analysis was done using the Statistica program, version 6.0. The significance of the influence of the $\mathrm{NaCl}$ concentration on the analyzed features was assessed by one-factorial analysis of variance, Tukey test, $\mathrm{p}<0.05$. 
On the basis of one- and two-factorial analysis of variance using Tukey test $\mathrm{p}<0.05$, homogeneous groups were distinguished.

\section{RESULTS AND DISCUSSION}

Tables 1 and 2 show the dependence of fresh and dry matter of wheat, rye, and triticale seedlings on the content of $\mathrm{NaCl}$ in the growth medium. An appropriate concentration of salt was chosen to make the growth and development of a majority of plants possible, despite the salinity of the medium, and to achieve major differentiation of the biometric features of the plants. It was found that with growing salinity the plants produced less biomass. Salinity of $150 \mathrm{mmol} \mathrm{NaCl} \mathrm{dm}^{-3}$ caused the greatest inhibition of growth, both in roots and shoots. Wheat and triticale growing in the medium with the highest $\mathrm{NaCl}$ concentration produced biomass of only $50 \%$ of that of the control plants, whereas rye biomass decreased at that concentration by $80 \%$. The growth of roots was more affected than that of shoots: both fresh and dry matter of seedlings grown in a medium containing $150 \mathrm{mmol} \mathrm{NaCl}$ in 1 litre produced
$80 \%$ less biomass than the control plants. It can be assumed that this was due to disturbances in water uptake, ion balance, and toxicity of sodium and chloride ions (Chinnusamy et al., 2005; Starck et al., 1995).

A stimulating effect of $\mathrm{NaCl}$ was found only in the growth of wheat grown in the medium containing $25 \mathrm{mmol}$ $\mathrm{NaCl} \mathrm{dm}{ }^{-3}$. It increased significantly the fresh matter of shoots and dry matter of roots. In earlier investigations conducted on wheat (Matuszak and Brzóstowicz, 2003), a stimulating influence of lower $\mathrm{NaCl}$ concentrations on the germination capability, the length of leaf, and fresh and dry matter of overground parts of seedlings was also found. Furthermore, an influnce of $\mathrm{NaCl}$ on the increase in cell membrane permeability, both in unhardened and hardened plants, was confirmed. An increase in low temperature resistance of the photosynthetic apparatus under the influence of $\mathrm{NaCl}$ was also found.

According to many authors, a majority of cultivated plants are typical glycophytes with low salt tolerance (Starck et al., 1995). Cereals exhibit moderate tolerance to salinity; barley has the greatest tolerance, wheat displays

T a b l e 1. Effect of $\mathrm{NaCl}$ on fresh and dry matter of shoots of wheat, rye, and triticale seedlings

\begin{tabular}{|c|c|c|c|c|c|c|}
\hline \multirow{2}{*}{$\begin{array}{c}\mathrm{NaCl} \\
\left(\mathrm{mmol} \mathrm{dm}^{-3}\right)\end{array}$} & \multicolumn{3}{|c|}{ Fresh matter (mg) } & \multicolumn{3}{|c|}{ Dry matter (mg) } \\
\hline & wheat & rye & triticale & wheat & rye & triticale \\
\hline 0 & $227.71 \mathrm{c} \mathrm{A}$ & $400.38 \mathrm{~d} \mathrm{~B}$ & $342.40 \mathrm{c} \mathrm{AB}$ & $40.21 \mathrm{~cd} \mathrm{~A}$ & $57.52 \mathrm{~b} \mathrm{~A}$ & $55.67 \mathrm{~b} \mathrm{~A}$ \\
\hline 25 & $274.76 \mathrm{~d} A$ & $250.09 \mathrm{c} \mathrm{A}$ & $308.1 \mathrm{bc} \mathrm{A}$ & $46.15 \mathrm{~d} A$ & $44.15 \mathrm{ab} \mathrm{A}$ & $55.56 \mathrm{ab} A$ \\
\hline 50 & $225.13 \mathrm{c} \mathrm{A}$ & $204.8 \mathrm{bc} \mathrm{A}$ & 316.24 bc B & $41.90 \mathrm{~cd} \mathrm{~A}$ & $43.51 \mathrm{ab} \mathrm{A}$ & $47.07 \mathrm{ab} A$ \\
\hline 75 & $166.48 \mathrm{~b} \mathrm{~A}$ & $171.3 \mathrm{ab} \mathrm{A}$ & $213.05 \mathrm{ab} B$ & $32.42 \mathrm{~b} \mathrm{~A}$ & $35.35 \mathrm{ab} \mathrm{A}$ & $37.80 \mathrm{ab} A$ \\
\hline 100 & $167.62 \mathrm{~b} \mathrm{~B}$ & $137.80 \mathrm{ab} A$ & $205.54 \mathrm{ab} C$ & $35.13 \mathrm{bc} \mathrm{AB}$ & 30.09 a A & $39.67 \mathrm{ab} B$ \\
\hline 150 & 113.37 a B & $68.86 \mathrm{a} \mathrm{A}$ & 127.00 a B & $24.32 \mathrm{a} \mathrm{A}$ & $22.03 \mathrm{a} \mathrm{A}$ & 25.44 a A \\
\hline
\end{tabular}

Deficiency of significant differences $(\mathrm{p}>0.05)$ : $\mathrm{a}, \mathrm{b}, \mathrm{c}-$ within the species; $\mathrm{A}, \mathrm{B}, \mathrm{C}-$ between the species.

T a b l e 2. Influence of $\mathrm{NaCl}$ on fresh and dry matter of roots of wheat, rye, and triticale

\begin{tabular}{|c|c|c|c|c|c|c|}
\hline \multirow{2}{*}{$\begin{array}{c}\mathrm{NaCl} \\
\left(\mathrm{mmol} \mathrm{dm}^{-3}\right)\end{array}$} & \multicolumn{3}{|c|}{ Fresh matter (mg) } & \multicolumn{3}{|c|}{ Dry matter (mg) } \\
\hline & wheat & rye & triticale & wheat & rye & triticale \\
\hline 0 & $275.21 \mathrm{bc} \mathrm{AB}$ & $155.22 \mathrm{c} \mathrm{A}$ & 334.39 c B & $22.41 \mathrm{c} \mathrm{A}$ & $13.55 \mathrm{~b} \mathrm{~A}$ & $22.54 \mathrm{~b} \mathrm{~A}$ \\
\hline 25 & 324.49 c B & $119.21 \mathrm{bc} \mathrm{A}$ & 285.13 bc B & $26.97 \mathrm{~d} B$ & $13.52 \mathrm{~b} \mathrm{~A}$ & $23.13 \mathrm{~b} \mathrm{~B}$ \\
\hline 50 & $258.28 \mathrm{~b} \mathrm{~B}$ & $117.40 \mathrm{bc} \mathrm{A}$ & 314.24 bc B & $22.00 \mathrm{c} \mathrm{B}$ & $12.97 \mathrm{~b} \mathrm{~A}$ & $18.80 \mathrm{ab} \mathrm{B}$ \\
\hline 75 & $111.24 \mathrm{a} \mathrm{A}$ & 103.42 bc A & $161.05 \mathrm{ab} B$ & $13.43 \mathrm{~b} \mathrm{~A}$ & $10.77 \mathrm{ab} \mathrm{A}$ & $16.16 \mathrm{ab} \mathrm{B}$ \\
\hline 100 & 115.93 a B & $64.88 \mathrm{ab} \mathrm{A}$ & 119.54 a B & $12.16 \mathrm{~b} \mathrm{~B}$ & $6.14 \mathrm{ab} \mathrm{A}$ & $13.52 \mathrm{a} B$ \\
\hline 150 & 64.38 a B & 20.39 a A & 76.58 a B & 7.52 a B & $2.60 \mathrm{a} \mathrm{A}$ & 8.74 a B \\
\hline
\end{tabular}

Explanations as in Table 1. 
lower tolerance, and rye and oats are relatively susceptible to salinity (Munns, 2002). Based on this study, it was hard to determine which of the tested species were more and which less susceptible to salinity. Investigations of the influence of $\mathrm{NaCl}$ on the fresh and dry matter of overground parts of seedlings (Table 1) revealed minor differences between species grown in the control solution and the $\mathrm{NaCl}$ solution. It was observed that triticale seedlings were characterized by the highest levels of fresh matter of the overground parts in comparison with the other tested species. In the analysis of the influence of $\mathrm{NaCl}$ on fresh and dry matter of roots (Table 2), it was found that rye seedlings produced the lowest biomass. On the contrary, minor differences between wheat and triticale seedlings grown on the control and $\mathrm{NaCl}$ solutions in terms of fresh and dry matter were observed. The reaction of plants depends eg on the growth stage (Munns, 2002), kind of salt, and external factors (Shannon and Grieve, 1999). Furthermore, there are differences between not only species but also cultivars of one species (Munns, 2002).

The impact of $\mathrm{NaCl}$ on the content of chlorophyll in the first leaves of wheat, rye, and triticale is shown in Fig. 1. Many authors have found that plants react to salinity by a reduced content of chlorophyll in leaves (Muranaka et al., 2002). This may be due to increased activity of chlorophyllases and accumulation of salt ions. In our study, a significantly higher chlorophyll content than in the control seedlings was found only in triticale which had grown in a medium containing $150 \mathrm{mmol} \mathrm{NaCl} \mathrm{dm}{ }^{-3}$. The other plants either showed no reaction to the presence of $\mathrm{NaCl}$ in the medium or had a lower content of chlorophyll. These findings indicate that plants react to salt contained in the medium in various manners. It was observed, comparing the reaction of the particular species to salt stress, that the triticale seedlings were indeed characterized by the greatest chlorophyll content in the first leaf.

Figure 2 presents the influence of $\mathrm{NaCl}$ on the intensity of photosynthesis. The presence of $\mathrm{NaCl}$ in the growth medium caused a decrease in photosynthesis intensity, which was greater in media with increasing concentrations of salt. Several authors have found that this phenomenon is caused by eg a lower chlorophyll content, closure of stomata (Muranaka et al., 2002; Starck et al., 1995), lower activity of RuBP-carboxylase (Flexas et al., 2004), disturbance in electron transport, and disorder in photosystem II (Muranaka et al., 2002). Furthermore, salt stress decreases biomass production affecting parameters connected with gas exchange and transpiration (Kalaji and Pietkiewcz, 1993), which was confirmed in this study. In their investigations of the impact of salinity on growth, photosynthesis, water potential, and leaf temperature of wheat seedlings (cv. Almari), Matuszak et al. (2004) found a decrease in photosynthesis intensity with increasing $\mathrm{NaCl}$ concentration, lowered water potential in leaves and, on the basis of thermal pictures analysis, growth of leaf temperature. In this case, the excess of salinity in the water solution reduced cell hydration and, in consequence, induced a fall in turgor. The fall inhibited the growth and caused a temperature increase in wheat seedling leaves.

The dependence of the average temperature $t_{m}$ at which the maximum delayed luminescence (IDL) was the lowest on the concentration of $\mathrm{NaCl}$ in the medium is presented in Fig. 3. In the case of triticale, results showing the effect of $\mathrm{NaCl}$ at concentrations up to $75 \mathrm{mmol} \mathrm{NaCl} \mathrm{dm}{ }^{-3}$ are only presented, due to the loss of samples. The reduction of the $t_{m}$ values with the increasing salt content in the medium
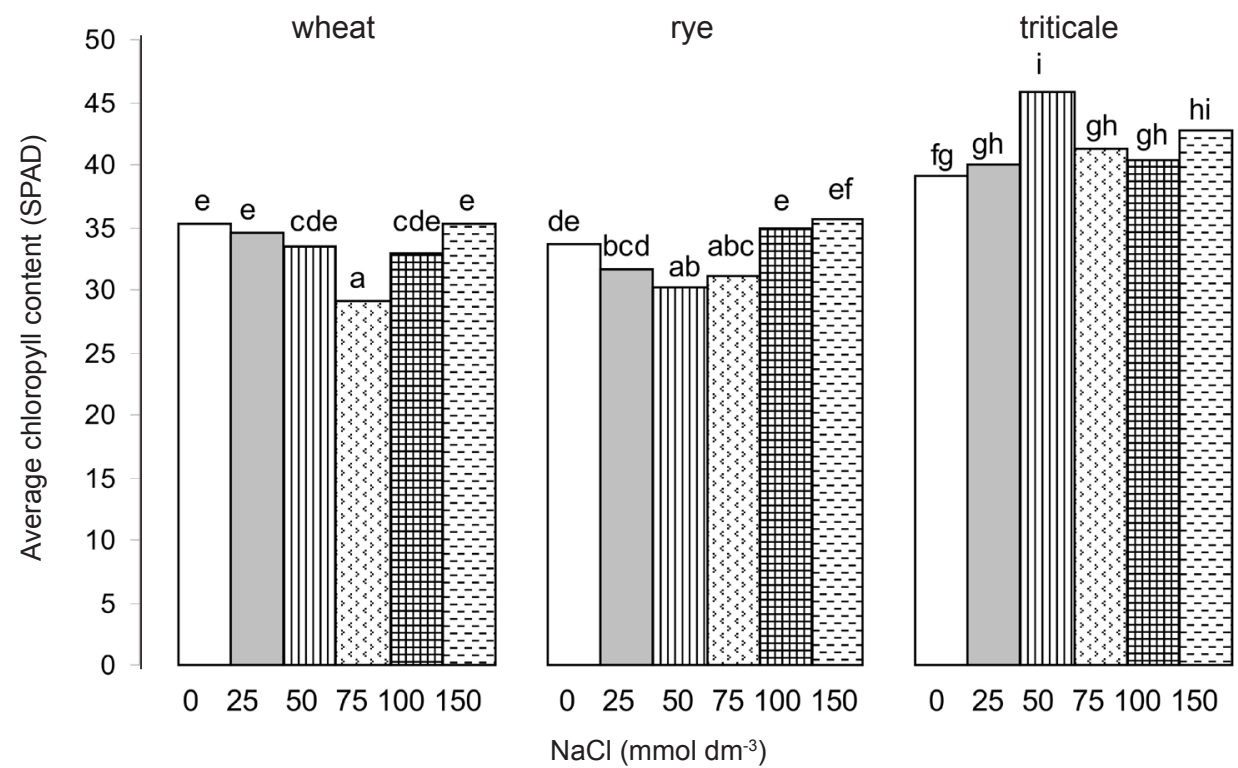

Fig. 1. Dependence of the chlorophyll content in the first leaf of wheat $c v$. Almari, rye $c v$. Amilo, and triticale $c v$. Tornado on the $\mathrm{NaCl}$ concentration. Numbers with the same letter mean that the differences are not significant at the level $p<0.05$. Tukey test - two-factorial analysis of variance. 

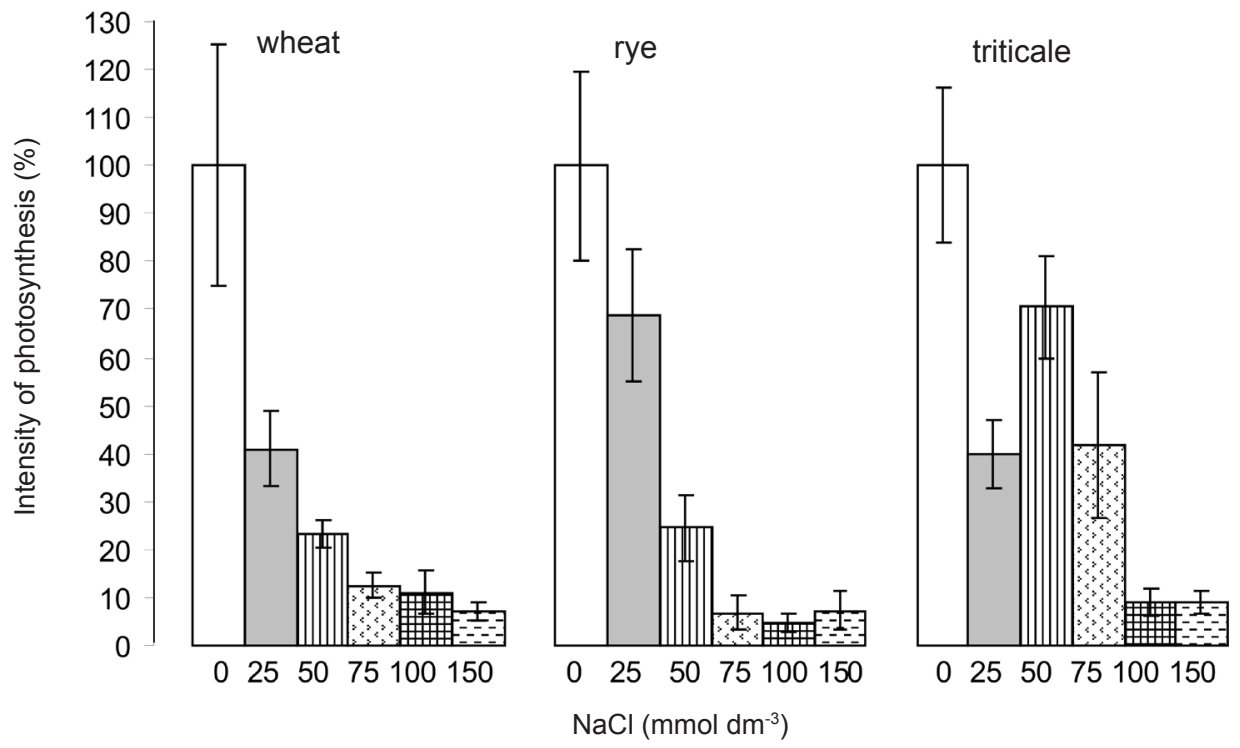

Fig. 2. Influence of $\mathrm{NaCl}$ on photosynthesis intensity in wheat $c v$. Almari, rye $c v$. Amilo, and triticale $c v$. Tornado $(100 \%=$ photosynthesis of control plants). Mean values of 6 replicates \pm standard deviation (SD).
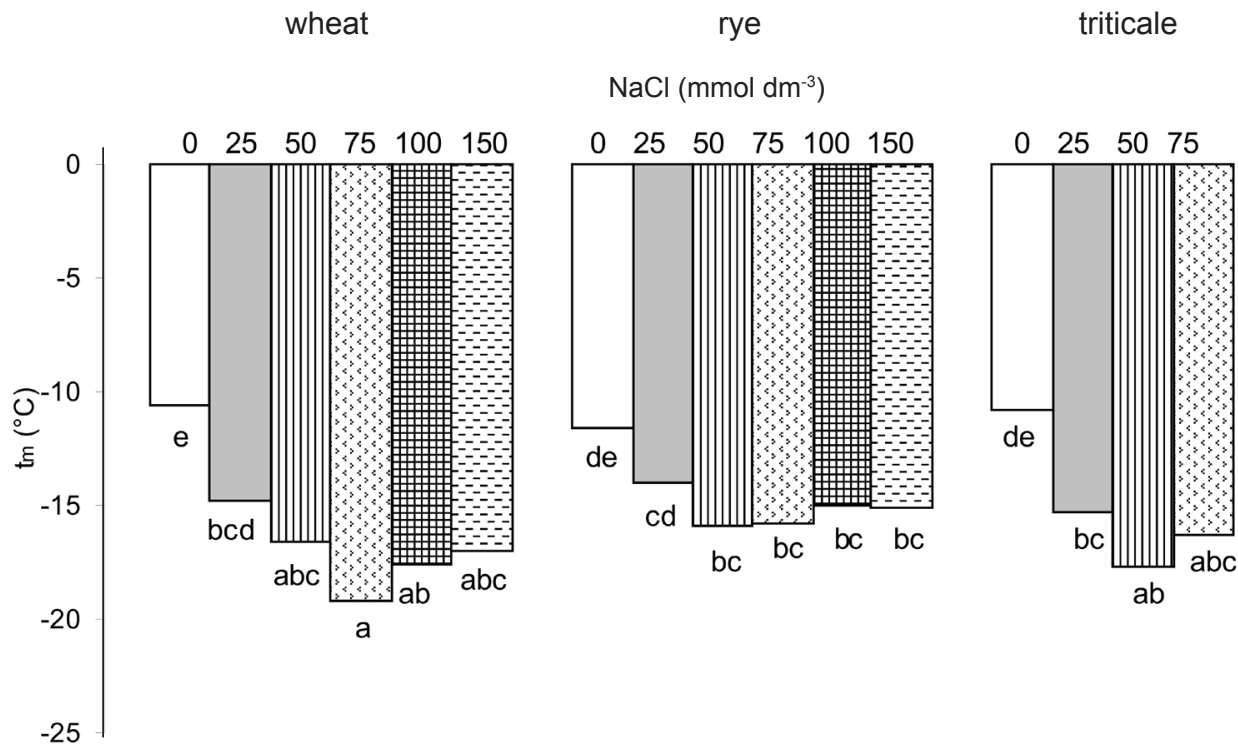

Fig. 3. Dependence of temperature $\left(\mathrm{t}_{\mathrm{m}}\right)$ at which maximum delayed luminescence (IDL) was reported on the $\mathrm{NaCl}$ concentration in wheat, rye and triticale hardened against low temperature. Explanations as in Fig. 1.

indicates a shift of the IDL maximum toward lower temperature. Besides, no significant differences in the value of the $\mathrm{t}_{\mathrm{m}}$ indicator between the tested species grown in the control solution and the $\mathrm{NaCl}$ solutions were observed. Brzóstowicz (1990), who studied the effect of low temperature on the intensity of the secondary component of leaf delayed luminescence, found that changes in this phenomenon (size and location of the maximum) depend on the temperature at which the electron transport between the $Q_{A}$ and $\mathrm{Q}_{\mathrm{B}}$ acceptors in photosystem II is blocked and on the potential gradient generated by hydrogen ion transport through the thylakoid membrane in a reaction coupled with photo- synthetic electron transport. In hardened plants, the electron transport and hydrogen ion transport can take place quite efficiently at a lower temperature than in non-hardened plants.

The results of this study have shown that the presence of $\mathrm{NaCl}$ in the medium blocks electron transport at the acceptor site of photosystem II at a lower temperature. Therefore, the resistance of the electron transport is higher than in the control plants. It can also be assumed that the lower values of $t_{m}$ may be caused by efficient accumulation and compartmentation of toxic ions in the vacuole, which further leads to decreased transport of $\mathrm{Na}^{+}$and $\mathrm{Cl}^{-}$into chloroplasts, hence causing little damage (Chinnusamy et al., 


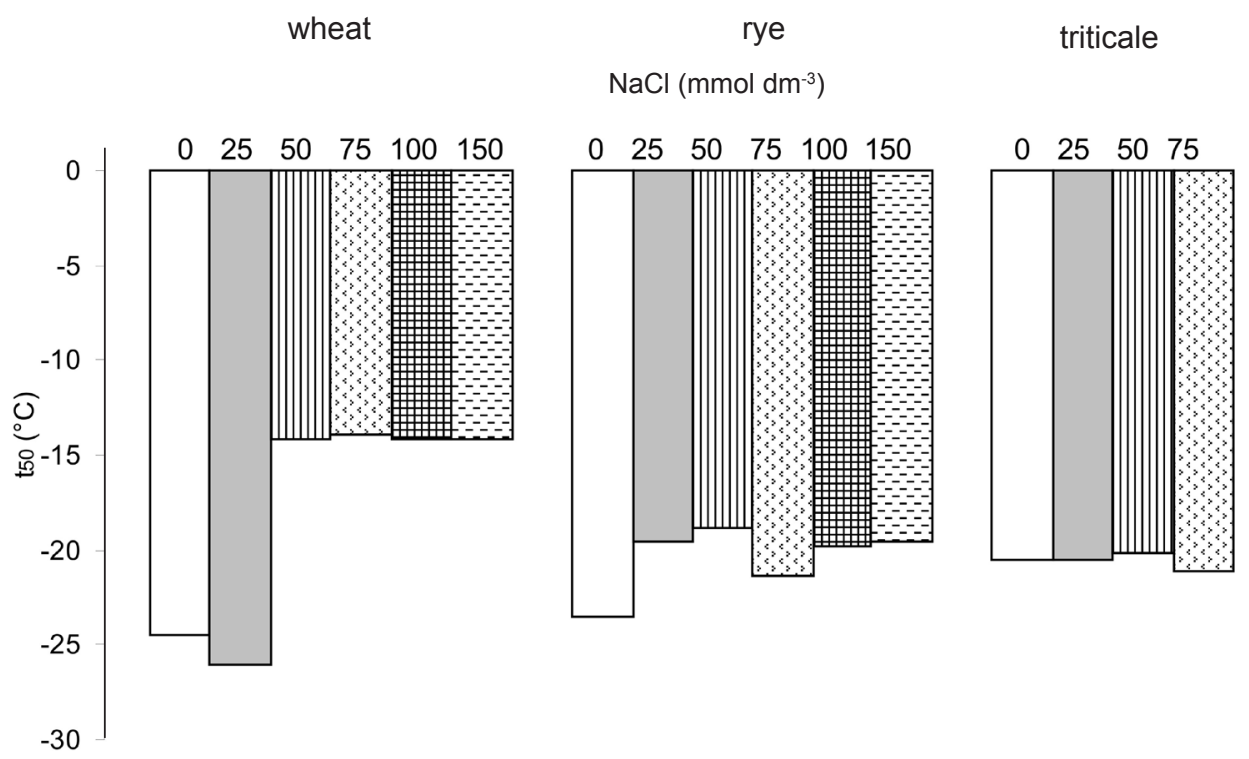

Fig. 4. Dependence of temperature $t_{50}(50 \%$ damage $)$ on the concentration of $\mathrm{NaCl}$ in the growth medium for wheat, rye, and triticale hardened for low temperature (standard deviation did not exceed $1.5^{\circ} \mathrm{C}$ ).

2005). The increased resistance of electron transport to low temperature may also be due to the synergetic activity of both the low temperature and salinity. Under the influence of salinity and hardening, plants synthesize factors protecting the photosynthetic apparatus (Aticia et al., 2003; Starck et al., 1995) and maintain the osmotic balance. This changes the chemical composition and properties of cell walls (thylakoid walls as well) - the amount of non-saturated acids increases, which causes maintenance of high activity of enzymes in the walls, particularly of the ATP-ases (Starck et al., 1995). Moreover, with increasing salinity the temperature of crystallization decreases and the process of intracellular freezing is delayed. These changes are correlated with an increased concentration of the cell liquid. These processes are involved in energy transfer, which in turn affects the activity of photosynthesis. The activities mentioned above and the decreased fluidity of membranes can increase the potential gradient in plants exposed to low stress temperature, which can be detected as a greater maximum of delayed luminescence intensity (Brzóstowicz, 2003).

The data presented in Fig. 4 show the dependence of the $t_{50}$ index on the concentration of $\mathrm{NaCl}$ in the growth medium for wheat, rye, and triticale which had been hardened against frost. With the exception of the triticale seedlings, whose cell walls did not react to the presence of $\mathrm{NaCl}$ in the medium, the two other species, particularly wheat, exhibited increased permeability of cell walls caused by the higher content of $\mathrm{NaCl}$ in the growth medium. Comparison of temperature values $t_{50}$ determined for the particular species revealed that wheat seedlings grown on $\mathrm{NaCl}$ solution at $25 \mathrm{mmol} \mathrm{dm}^{-3}$ were characterized by a lower $\mathrm{t}_{50}$ temperature value, but those grown in the presence of higher $\mathrm{NaCl}$ concentrations displayed the highest temperature values. These facts imply greater sensitivity to low temperature of the cell membrane in wheat seedlings than in rye and triticale membranes. An increase in $t_{50}$ (temperature that induced a $50 \%$ leak of electrolytes from the damaged tissue) indicated that the cell walls of rye and wheat were more sensitive to low temperature when they were grown in a $\mathrm{NaCl}$ containing medium. Changes in the cell wall permeability can be caused by both the increased salinity and low temperature. Salinity leads eg to depolarization of cell walls and changes in the chemical composition of lipids (Mansour and Salama, 2004) and opens ion and water channels, which causes water outflow with ions. Under the low temperature stress, dehydration of cells caused by crystallization of extracellular water leads to alterations in the cell wall structure and formation of lipid areas lacking protein molecules in the cell wall. As a result of low temperature, a thermotropic change in the lipid phase occurs and phase transition of the cell membrane takes place - the liquid crystal phase changes into a crystalline one (gel) (Badea and Basu, 2009). These changes often lead to denaturation and dissociation of proteins, eg enzymatic proteins, which leads to changes in the activity of numerous enzymes associated with cell walls (eg ATP-ase, which is responsible for the transport of many substances and ions). Cell walls of damaged cells cease to be semipermeable (Badea and Basu, 2009; Starck et al., 1995).

The results obtained with the conductometric method indicate that $\mathrm{NaCl}$ affects strongly the permeability of the cell walls of the tested seedlings. In this case, the negative influence of accumulation of two stress factors caused the damage. Such injuries of the cell walls were observed in wheat and rye, but not in triticale. On the other hand, luminescence has proved that the presence of $\mathrm{NaCl}$ in the growth medium increased the resistance of the photosynthetic apparatus, because the electron transport was blocked at a lower temperature than in control plants. 
An increase in frost resistance of spinach along with an increase in the $\mathrm{NaCl}$ concentration in the hydroponics culture medium was also observed by Schmidt et al. (1986). Both the osmolality of the leaf sap and frost resistance of the leaves were linearly correlated with the salt concentration in the hydroponics culture medium. In their investigations on the cauliflower, Fuller and Eed (2003) found that the most salt-resistant plants were also more frost tolerant.

At the beginning of this experiment, it was assumed that moderate salt stress might promote frost hardening, but it was difficult to predict to what extent. In literature, the phenomenon of cross-tolerance, when a plant exposed to one stress factor may become more tolerant to another factor, has been known for a long time (Płażek and Żur, 2003; Starck et al., 1995; Titov et al., 2003). Acquiring tolerance to one stress often decreases sensitivity for other stress factors. For example, Lichtenthaler (1996) reports that small doses of stress factors (ie deficiency of water) cause plant hardening, thereby lowering the sensitivity to other stress factors such as cold or salinity. Long-lasting effects of low concentrations of disadvantageous factors sometimes lead to growth at tolerance and stable acclimatization or even plant adaptation. Those processes occur in anatomical, morphological, biochemical, and physiological modifications both in photosynthesis and in donor-acceptor reactions. The results of biometric assays and assessment of frost resistance have shown that seedlings that developed larger shoots and roots if grown in a medium containing a low amount of $\mathrm{NaCl}\left(25 \mathrm{mmol} \mathrm{dm}^{-3}\right)$ and those that had not suffered under the influence of salt exhibited increased resistance of the photosynthetic apparatus to low temperature. This was indicated by a lower $\mathrm{t}_{\mathrm{m}}$ value in plants that grew in a medium with higher salinity, as compared with the control plants. On the other hand, damage done to cell walls (assessed by conductometry) indicated serious changes in cell wall permeability.

As shown by the presented investigations and professional literature reports, plant resistance to simultaneous salt and frost temperature stress depends on the plant species.

The luminescence measurements used in the analyses of the leaves of the seedlings provide additional information about the plant resistance or sensitivity to stress, especially about the sensitivity of the electron transport in the initial photosynthetic reactions.

Complex measurements using different methods provide more complete information about the physiological condition of plants exposed to stress factors.

The enhanced resistance to low temperature shown by seedlings growing in the saline medium was probably due to the very low osmotic potential of the cell liquid caused by both ion accumulation and active osmo-regulation. This influences further water uptake and protects the cell structures. The increased concentration of cell liquid delays crystallization of water.
CONCLUSIONS

1. The highest salt content in the growth medium $\left(150 \mathrm{mmol} \mathrm{NaCl} \mathrm{dm}^{-3}\right)$ significantly decreased the weight of both the roots and shoots of the tested cereal: wheat, rye, triticale in comparision to control solution.

2. Low salinity of the Hoagland solution $\left(25 \mathrm{mmol} \mathrm{dm}^{-3}\right)$ stimulated the growth (fresh and dry matter) of wheat $c v$. Almari seedlings.

3. A majority of the cereals reacted to increasing salinity of the medium by reduced growth of shoots and roots, and the individual reactions varied.

4. The $t_{50}$ index assessed by conductometry indicated that cell walls of wheat and rye growing in the saline medium were more susceptible to low temperature than those of triticale (grown in the same conditions).

5. The lowering of the temperature at which delayed luminescence was at its maximum following an increase in the $\mathrm{NaCl}$ content in the medium indicates blockage of electron transport at the acceptor site of photosystem II at a lower temperature.

\section{REFERENCES}

Arzani A., 2008. Improving salinity tolerance in crop plants: a biotechnological view. In: Vitro Cell. Dev. Biol. Plant, 44, 373-383.

Aticia O. and Nalbantoglu B., 2003. Antifreeze proteins in higher plants. Phytochemistry, 64, 1187-1196.

Badea C. and Basu S.K., 2009. The effect of low temperature on metabolism of membrane lipids in plants and associated gene expression. Plant Omics J., 2(2), 78-84.

Beck E.H., Fettig S., Knake C., Hartig K., and Bhattarai T., 2007. Specific and unspecific responses of plants to cold and drought stresse. J. Biosci., 32(3), 501-510.

Brzóstowicz A., 1990. Determination of delayed photosynthetic apparatus luminescence as a possible method of frost resistance evaluation in wheat leaves. Acta Physiol. Plant., 12 (3), 187-191.

Brzóstowicz A., 1993. A microccomputer set-up to study temperature effects on intensity of delayed luminescence of leaf fragments (in Polish). Zeszyty Naukowe AR Szczecin Rolnictwo, s. Techniczna, 159(56), 41-47

Brzóstowicz A., 2003. Luminescence method for evaluation of plants frost resistance (in Polish). Acta Agrophysica, 93, $5-10$.

Brzóstowicz A. and Prokowski Z., 2003. Conductometric method for evaluation of plants frost resistance (in Polish). Acta Agrophysica, 93, 11-15.

Chinnusamy V., Jagendorf A., and Zhu J-K., 2005. Understanding and improving salt tolerance in plants. Crop Sci., 45, 437- 448 .

Flexas J., Bota J., Loreto F., Cornic G., and Sharkey T.D., 2004. Diffusive and Metabolic Limitations to Photosynthesis under Drought and Salinity in C3 Plants. Plant Biology, 6, 269-279.

Flint H.L., Boyce B.R., and Brattie D.J., 1967. Index of injury, a useful expression of freezing injury to plant tissues as determinated by the electric method. Can. J. Plant Sci., 47, 229-239. 
Flowers T.J., 2004. Improving crop salt tolerance. J. Exp. Bot., 55(396), 307-319.

Fuller M.P. and Eed M.H.I., 2003. The development of multiple stress-resistant cauliflower using mutagenesis in conjunction with a microshoot tissue culture technique. Acta Horticulturae, 618, 71-76.

Kalaji M.H. and Pietkiewicz S., 1993. Salinity effects on plant growth and other physiological processes. Acta Physiol. Plant., 15(2), 89-124.

Lichtenthaler H.K., 1996. Vegetation stress: an introduction to the stress concept in plants. J. Plant Physiol., 148, 4-14.

Mahajan S. and Tuteja N., 2005. Cold, salinity and drought stresses: an overview. Arch. Biochem. Biophys., 444, 139-158.

Mansour M.M.F. and Salama K.H.A., 2004. Cellular basis of salinity tolerance in plants. Environ. Exp. Botany, 52, 113-122.

Matuszak R., Baranowski P., Walczak R.T., and Brzóstowicz A., 2004. Evaluation of the effect of salinity on the growth, photosynthesis, water potential and temperature of leaves of wheat seedlings of Almari cultivar (in Polish). Acta Agrophysics, 110, 97-103.

Matuszak R. and Brzóstowicz A., 2003. Comparison of effect of $\mathrm{NaCl}$ on growth and frost resistance of two wheat cultivars (in Polish). Acta Agrophysica, 82, 119-129.

Mohammadi S.K., Shekari F., Fotovat R., and Darudi A., 2012. Effect of laser priming on canola yield and its components under salt stress. Int. Agrophys., 26, 45-51.

Monje O.S. and Bugbee B., 1992. Inherent limitations of nondestructive chlorophyll meters: a comparison of two types of meters. Sci. Hort., 27, 69-71.
Munns R., 2002. Coparative physiology of salt and water stress. Plant Cell Environ., 25, 239-250.

Muranaka S., Shimizu K., and Kato M., 2002. Ionic and osmotic effects of salinity on single-leaf photosynthesis in two wheat cultivars with different drought tolerance. Photosynthetica, 40(2), 201-207.

Plażek A. and Żur I., 2003. Cold - inducced plant resistance to necrotrophic patogens and antioxidant enzyme activities and cell membrane permeability. Plant Sci., 164, 1019-1028.

Pocock T.H., Hurry V., Savitch L.V., and Huner N.P.A., 2001. Susceptibility to low-temperature photoinhibition and the acquisition of freezing tolerance in winter and spring wheat: The role of growth temperature and irradiace. Physiol. Plant., 113, 499-506.

Schmidt J.E., Schmitt J.M., Kaiser W.M., and Hincha D.K., 1986. Salt treatment induces frost hardiness in leaves and isolated thylakoids from spinach. Planta, 168, 50-55.

Shannon M.C. and Grieve C.M., 1999. Tolerance of vegetable crops to salinity. Sci. Hort., 78, 5-38.

Starck Z., Chołuj D., and Niemyska B., 1995. Physiological aspects of plant responses to stress factors (in Polish). Wydawnictwo SGGW, Warsaw, Poland.

Titov A.F., Talanova V.V., and Akimova T.V., 2003. The effect of roots treatment with various strss agents on plant coldand heat-tolerance. Russ. J. Plant Physiol., 50(1), 84-89.

Veisz O., Braun H.J., and Bedo Z., 2001. Plant damage after freezing, and the frost resistance of varieties from the facultative and winter wheat observation nurseries. Euphytica, 119, 179-183. 